\title{
Temporal Variation of Drinking Water Quality Parameters for Sulaimani City, Kurdistan Region, Iraq
}

\author{
Jwan Bahadeen Abdullah and Yaseen Ahmed Hamaamin* \\ Department of Civil Engineering, College of Engineering, University of Sulaimani, KRG, Iraq
}

\section{A B S T R A C T}

Water is vital for all forms of life on earth. Assessing the quality of water especially drinking water is one of the important processes worldwide which affect public health. In this study, the quality of drinking water in Sulaimani City is monitored for a study period of 1 year. A total number of 78 water samples were collected and analyzed for 17 physical and chemical properties of water supply system to the city. Samples of water are collected from the three main sources of drinking water for Sulaimani City (Sarchnar, Dukan line-1, and Dukan line-2) from February to August 2019. The results of physical and chemical parameters of collected water samples were compared with the World Health Organization and Iraqi standards for drinking water quality. The results of this study showed that mostly all parameters were within the standards except the turbidity parameter which was exceeded the allowable standards in some cases. This research concluded that, in general, the quality of drinking water at the three main sources of Sulaimani City is suitable and acceptable for drinking.

Index Terms: Seasonal, Variation, Water, Quality, Sulaimani

\section{INTRODUCTION}

One of the most critical and important natural resources to sustain life is water. Therefore, there is an increasing awareness that assessing the quality of water is essential for abundant activities such as drinking, agricultural, industrial, hydropower generation, and recreational purposes [1], [2] and [3]. Worldwide impaired quality, scarcity, and pressure on water resources due to the growing demands, requires the critical researches on quantity and quality of water [1], [4] and [5]. Consequently, the necessary step in national water planning and management is assessing the quality of water [6], [7], [8]

\begin{tabular}{|l|l|}
\multicolumn{2}{|c|}{ Access this article online } \\
\hline DOI: $10.21928 /$ undjst.v4n2y2020.pp99-106 & $\begin{array}{l}\text { E-ISSN: 2521-4217 } \\
\text { P-ISSN: 2521-4209 }\end{array}$ \\
\hline
\end{tabular}

Copyright (C) 2020 Abdullah and Hamaamin. This is an open access article distributed under the Creative Commons Attribution NonCommercial No Derivatives License 4.0 (CC BY-NC-ND 4.0) and [9]. Global water resource contamination is increasing due to diverse human activities and population growth, which raised international alarm about quality of water [6]. Regular monitoring the quality of water and advising ways for protecting water resources are necessary in all countries, especially in developing countries which have a rapid urbanization [10], [11] and [12]. Water quality can be defined in terms of its chemical, physical, and biological characteristics which show the suitability of water for different uses such as drinking, industrial, agricultural, and domestic. Observing water quality parameters for annually (or with any intervals) sampled water are the key for detecting information about the pollution level and the quality variation in water over trends of time [2], [3], [5], [7] and [8]. According to the reports conducted by the World Health Organization (WHO) in Iraq show that $25 \%$ of childhood deaths are due to the water borne diseases that can be prevented. In terms of obtaining safe water and sanitation, the condition in Kurdistan region is better compared with the other cities in Iraq but still problems 
with environmental issues are existing [13]. Issa and Alrawi [14] developed water quality index for Erbil's three water treatment plants, they found that the quality of water fallen within the good level of water quality.

According to the official directorate of water, the quality of drinking water in Sulaimani City is acceptable in terms of physiochemical and biological properties, but one of the concerned problems of the city's water supply is the yellow tint occurred in a certain time in the years, especially in spring and autumn [15]. The main sources of municipal drinking water in Sulaimani city are Sarchnar, Dukan line-1, and Dukan line-2, due to unexpected growth population in the city and economic problems, continuous water supply does not exist in the city, it has intermittent water supply of about few hours each 2 days [16]. The main objective of this study is monitoring and assessing the quality of municipal drinking water supply for the Sulaimani City by evaluating the chemical and physical characteristics of water sampled from the main sources of drinking water in the city.

\section{MATERIALS AND METHODS}

\subsection{Study Area}

Sulaimani City is located in the north part of Iraq which is one of the major cities in the Iraqi Kurdistan region with a population of over 1 million. The city is stretched between two mountains at the intersection point of Longitude $45.44312^{\circ}$ and Latitude of $35.55719^{\circ}$ with average level of about $850 \mathrm{~m}$ above the sea level. The weather of the city is dry and warm in summer with an average temperature of $31.5^{\circ} \mathrm{C}$, while the weather is cold and wet during winter season with average temperature of $7.6^{\circ} \mathrm{C}$ [16] and [17]. Fig. 1 shows water treatment plant and sampling locations which are both in Sulaimani Governorate.

\subsection{Water Quality Parameters}

In this study, 17 physical and chemical water parameters were used to measure the quality of drinking water for Sulaimani City. Temperature, electrical conductivity (EC), total dissolved solids (TDS), salinity, PH, turbidity, free chlorine, total chlorine, total alkalinity, hardness, calcium, ammonia, ammonium, chloride, fluoride, nitrate nitrogen, and nitrate parameters were measured in the study.

Temperature as one of important water quality parameters has a great effect on growth and activity of aquatic life. Temperature affects the solubility of oxygen in water which consequently affects the life of aquatic organisms.
Furthermore, biochemical reactions of aquatic bacteria can be doubled for each $10^{\circ} \mathrm{C}$, to a certain limit of temperature [18] and [19].

EC of water measures the ionic content of a water sample which indicates the range of alkalinity and hardness of water. This parameter affects the acceptability of water for drinking purpose because it impacts the taste of water significantly. The amount of conductivity in any sample of water is influenced by the amount of TDS concentration which is another important parameter in monitoring the quality of water. However, lime scaling and buildup can be occurred from high alkaline water. Dissolve solids can occur in water from dissolving of soil minerals while it is in touch with soil layers. Runoff from residential areas and farming, leaching pollutant from soil and industrial or sewage treatment to water resources can be other sources of TDS [9] and [20]. Salinity is a parameter that related to the presence of salt content in water. Suitability of water may be rendered by the amount of salt content in it [21], [22] and [23].

$\mathrm{PH}$ is a parameter that indicates whether the water is acid or basic. Furthermore, it shows if the water is suitable or not for various purposes. $\mathrm{PH}$ has a direct relation with every phase of water treatment processes. Low $\mathrm{pH}$ cause corrosion in water distribution systems, on the other hand, high $\mathrm{pH}$ affects the palatability of water [21] and [22].

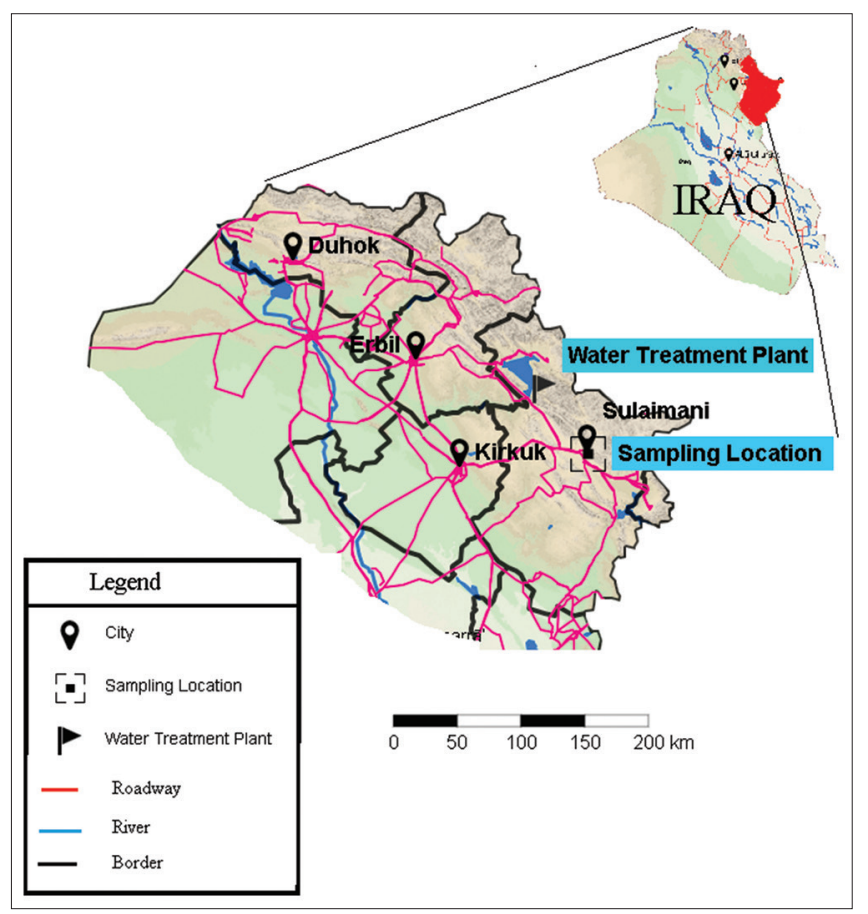

Fig. 1. Study area. 
Turbidity of water is occurred by the presence of suspended solids such as clay, silt, and other microscope organisms that are the very fine hard to be removed by routine water treatment methods. This parameter affects the acceptability of consuming water for drinking or other uses especially in certain industries [19].

Chlorination is the most universal method of water disinfection, which is efficient and powerful way in the treatment process. After completion of the disinfection process, extra chlorine can remain in the form of residual chlorine which is very important, because it insures protecting water from recontamination especially in old water distribution systems [21].

Total alkalinity is the size of water response with $\mathrm{H}+$ ions and sometimes is indicated as alkali level. Alkalinity relates with the scale deposition and corrosion in distribution systems. This parameter can be attributed to carbonates and hydroxides in natural water. The unit used for expressing alkalinity is $\mathrm{mg} / 1 \mathrm{CaCO}_{3}[24]$.

Ammonia and ammonium concentration express as $\mathrm{mg} / \mathrm{lN}$ and $\mathrm{mg} / 1 \mathrm{NH}_{3}$, respectively. These parameters indicate the possibility of pathogenic micro-organisms presence in water and sewage pollution of water. In water treatment, presence of ammonia with high level can impair the chlorination process of water [19] and [21].

The characteristic of water that improves its palatability and shows the suitability of water for drinking purpose is hardness $\left(\mathrm{mg} / 1 \mathrm{CaCO}_{3}\right)$ which is the soap destroy capacity of water. The main constituents of hardness are calcium and magnesium which are the widespread abundance metals in the formation of rocks [23].

Calcium is the most important element which ensures the normal growth and health of human body. Water with high amount of calcium consider as very palatable and acceptable water. Calcium is the primary constituent of hardness and it is very beneficial to health. Its concentration in water expressed as $\mathrm{mg} / \mathrm{l} \mathrm{Ca} \mathrm{[20].}$

Naturally, fluoride occurs rarely in waters, main sources of this element in water are public water supply fluoridation and industrial discharges. Fluoride should be added to water supply because of its importance for growing children teeth and reducing tooth decay. Fluoride concentration is expressed as $\mathrm{mg} / \mathrm{l} \mathrm{F}$. Chloride $(\mathrm{mg} / \mathrm{l} \mathrm{Cl})$ is the parameter which can be consider for accepting the palatability of water and it does not have hazard to human health. High amount of chloride raises the salty taste of water [16].

Nitrate nitrogen $(\mathrm{mg} / \mathrm{l} \mathrm{N})$ and nitrate $(\mathrm{mg} / \mathrm{l} \mathrm{NO}$ ) can be found in natural water due to the organic wastes, sewage discharges, farming fertilizer, runoff from surfaces, plants nitrogen fixing, and bacterial oxidation. High level concentration of nitrate is hazardous to human, especially infants because of its reaction with blood hemoglobin which causes methemoglobinemia [21].

\subsection{Sample Collection and Data Analysis}

Water samples were collected from the three main water distribution pipes on weekly bases and after rainfall events from three main sources of drinking water in Sulaimani City, Sarchnar, Dukan line 1, and Dukan line 2. Water samples were obtained at the same time and location from the main Sarchnar Control station where the three main distribution lines located which feed the city with drinking water supply. The date and time of samplings were altered by rainfall events and any other expected changes which can affect the quality of water.

Sarchnar water is natural spring water source, is pumped to the city without any treatment process except chlorination. The other two water supply main lines Dukan 1 and 2 are from the city's water treatment plant- 1 and plant 2 which are located in Peer Qurban (N 35.88808 and E 44.99651 $)$, receive water from lesser Zab River downstream of water from Dukan Lake. In year of 2018, Sulaimani City received following average amount of water from each source: $32535559 \mathrm{~m}^{3} /$ year from Sarchanr, $16721500 \mathrm{~m}^{3} /$ year from Dukan1, and $58893329 \mathrm{~m}^{3} /$ year from Dukan 2. Water samples were collected for winter, spring, and summer seasons between months February and August 2019. The samples were preserved in clean plastic bottles, and transferred to laboratory for analyzing physical and chemical parameters according to the defined methods in the standard methods for examination water and wastewater [25]. Physical parameters such as temperature, $\mathrm{PH}$, conductivity, TDS, and salinity were analyzed and recorded in situ immediately after running the water tabs for about 1 min and collecting the samples using Palintest Multi-Parameter Pocket meter (PT162). As soon as water samples were arrived laboratory, turbidity test and free chlorine and total chlorine test were conducted using Hanna Turbidity meter (HI98703-02) and Palintest spectrophotometer 7500 (7500 2180072). After that the remained water parameters were conducted using Palintest spectrophotometer 7500 (7500 2180072). Water samples lab results of the tests were evaluated and 
compared with the WHO water standards [19] and Iraqi water standards [26] for drinking water (Table 1).

\section{RESULTS AND DISCUSSION}

In this study, a total of 78 samples were collected and analyzed for 17 physical and chemical properties of water from the three main sources of drinking water in Sulaimani city (Sarchnar, Dukan line1, and Dukan line2) from February to August 2019. Table 2 shows the descriptive statistics of all water quality parameters test results obtained in the study.

In this study, the value of temperature for water samples collected from Sarchnar was close to the value of Dukan 2

TABLE 1: Drinking water standards [19] and [26]

\begin{tabular}{lcc}
\hline Parameter & WHO standards & Iraqi standards \\
\hline $\mathrm{PH}$ & $6.5-8.5$ & $6.5-8.5$ \\
Conductivity $(\mu \mathrm{s} / \mathrm{cm})$ & 600 & 1500 \\
TDS $(\mathrm{mg} / \mathrm{l})$ & 1000 & 1000 \\
Alkalinity $\left(\mathrm{mg} / \mathrm{l} \mathrm{CaCO}{ }_{3}\right)$ & 600 & -- \\
Turbidity $(\mathrm{NTU})$ & 5 & 5 \\
Free Chlorine $(\mathrm{mg} / \mathrm{l})$ & 5 & 5 \\
Hardness $\left.(\mathrm{mg} / \mathrm{l} \mathrm{CaCO})_{3}\right)$ & 500 & 500 \\
Calcium $(\mathrm{mg} / \mathrm{l} \mathrm{Ca})$ & 75 & 50 \\
Ammonia $\left(\mathrm{mg} / \mathrm{l} \mathrm{NH} \mathrm{H}_{3}\right)$ & 1.5 & -- \\
Fluoride $(\mathrm{mg} / \mathrm{l} \mathrm{F})$ & $0.7-1.5$ & -- \\
Chloride $(\mathrm{mg} / \mathrm{l} \mathrm{Cl})$ & 250 & 250 \\
Nitrate Nitrogen $\left(\mathrm{mg}^{\prime} / \mathrm{N}\right)$ & 10 & -- \\
Nitrate $\left.(\mathrm{mg} / \mathrm{l} \mathrm{NO})_{3}\right)$ & 50 & 50 \\
\hline
\end{tabular}

which was ranged between 15.8 and $20.4^{\circ} \mathrm{C}$. The temperature of samples from Dukan 1 was lower in winter season $\left(14^{\circ} \mathrm{C}\right)$ and higher in summer season $\left(23.1^{\circ} \mathrm{C}\right)$. In general, the average value temperature of collected samples during the period of study was $17.8^{\circ} \mathrm{C}$ for Sarchnar, $19^{\circ} \mathrm{C}$ for Dukan 1, and 18.6 for Dukan 2 (Fig. 2), while Sarchnar source is a spring and the intake from this source located at the source location which makes it is less affected by temperature rise during summer season compared to the other sources which are from Lesser Zab River.

While there were some strong correlations between the three parameters (TDS, EC, and salinity), only TDS changes shown in Fig. 3. The TDS values starting with the minimum value in the middle period of winter season and continuous rising until March and then falling again to the minimum value in the beginning of April during the intensive rainfall occurred in Kurdistan region and finally rising the values to the maximum value in August and continuous approximately with the same level to the end of summer season. This fluctuating of TDS may be due to contribution of groundwater during dry season to the river water, while it was low during flood season because of more rainfall runoff contribution to the river flow during spring months.

According to the WHO standards [19] and Iraqi standards [26], the range of $\mathrm{PH}$ should be between 6.5 and 8.5. In this study, minimum value of $\mathrm{PH}$ for all samples was 7.32 for Sarchnar source and the maximum value was 8.23 for Dukan 2. Fig. 4

TABLE 2: Descriptive statistics of water quality parameters for samples collected from main sources of drinking water of Sulaimani City; Sarchnar, Dukan line 1, and Dukan line 2

\begin{tabular}{|c|c|c|c|c|c|c|c|c|c|c|c|c|c|c|c|}
\hline \multirow[t]{2}{*}{ Parameter } & \multicolumn{5}{|c|}{ Sarchnar } & \multicolumn{5}{|c|}{ Dukan Line 1} & \multicolumn{5}{|c|}{ Dukan Line 2} \\
\hline & Min. & Max. & Mean & Med. & $\begin{array}{l}\text { Std. } \\
\text { dev. }\end{array}$ & Min. & Max. & Mean & Med. & $\begin{array}{l}\text { Std. } \\
\text { dev. }\end{array}$ & Min. & Max. & Mean & Med. & $\begin{array}{l}\text { Std. } \\
\text { dev. }\end{array}$ \\
\hline Temperature & 15.8 & 19.6 & 17.8 & 18 & 0.84 & 14 & 23.1 & 19.0 & 19.6 & 2.90 & 15.8 & 20.4 & 18.6 & 19.15 & 1.32 \\
\hline Conductivity & 357 & 562 & 461 & 455 & 79.23 & 342 & 566 & 466 & 452 & 78.79 & 333 & 537 & 435 & 437 & 75.56 \\
\hline TDS & 251 & 398 & 327 & 322 & 55.29 & 245 & 402 & 331 & 321 & 56.15 & 235 & 381 & 309 & 310 & 53.70 \\
\hline Salinity & 168 & 269 & 220 & 217 & 38.15 & 163 & 271 & 223 & 217 & 39.80 & 157 & 258 & 208 & 210 & 38.01 \\
\hline $\mathrm{PH}$ & 7.32 & 8.1 & 7.7 & 7.6 & 0.21 & 7.63 & 8.05 & 7.66 & 7.71 & 0.29 & 7.44 & 8.28 & 7.72 & 7.66 & 0.24 \\
\hline Turbidity & 0.28 & 10.5 & 1.9 & 1.41 & 2.23 & 0.26 & 11.6 & 1.93 & 0.88 & 2.69 & 0.31 & 14.1 & 2.43 & 1.15 & 3.11 \\
\hline Free chlorine & 0.15 & 0.92 & 0.64 & 0.69 & 0.15 & 0.11 & 0.53 & 0.33 & 0.36 & 0.12 & 0.65 & 1.96 & 1.05 & 0.96 & 0.34 \\
\hline Total chlorine & 0.17 & 0.94 & 0.67 & 0.72 & 0.14 & 0.17 & 0.53 & 0.35 & 0.37 & 0.11 & 0.66 & 1.98 & 1.07 & 1 & 0.33 \\
\hline Alkalinity & 135 & 220 & 190 & 203 & 26.98 & 130 & 235 & 191 & 200 & 28.79 & 135 & 200 & 169 & 173 & 19.60 \\
\hline Ammonia & 0 & 0.08 & 0.03 & 0.02 & 0.02 & 0 & 0.04 & 0.02 & 0.02 & 0.01 & 0 & 0.05 & 0.02 & 0.02 & 0.01 \\
\hline Ammonium & 0 & 0.08 & 0.03 & 0.03 & 0.02 & 0 & 0.05 & 0.03 & 0.03 & 0.02 & 0 & 0.06 & 0.02 & 0.03 & 0.02 \\
\hline Hardness & 121 & 175 & 152 & 151 & 17.55 & 124 & 193 & 153 & 154 & 17.39 & 128 & 171 & 145 & 144 & 12.42 \\
\hline Calcium & 48 & 70 & 61 & 63 & 6.62 & 50 & 78 & 62 & 62 & 7.03 & 52 & 68 & 59 & 58 & 4.65 \\
\hline Fluoride & 0 & 0.61 & 0.2 & 0.19 & 0.18 & 0.01 & 0.54 & 0.21 & 0.18 & 0.17 & 0 & 0.49 & 0.21 & 0.2 & 0.14 \\
\hline Chloride & 0 & 18 & 5 & 5 & 3.75 & 0 & 15 & 4 & 4 & 3.13 & 0 & 9 & 4 & 2 & 2.62 \\
\hline Nitrate (N) & 2.3 & 5.24 & 3.5 & 3.16 & 1.01 & 2.34 & 5.14 & 3.4 & 3.03 & 0.9 & 2.24 & 6.3 & 3.6 & 3.11 & 1.23 \\
\hline Nitrate $\left(\mathrm{NO}_{3}\right)$ & 10.4 & 23.6 & 15.4 & 14 & 4.46 & 10.4 & 22.8 & 15.0 & 13.60 & 4.0 & 10 & 28 & 16.1 & 14 & 5.40 \\
\hline
\end{tabular}


Jwan Bahadeen Abdullah and Yaseen Ahmed Hamaamin: Quality of Drinking Water Supply for Sulaimani, Iraq

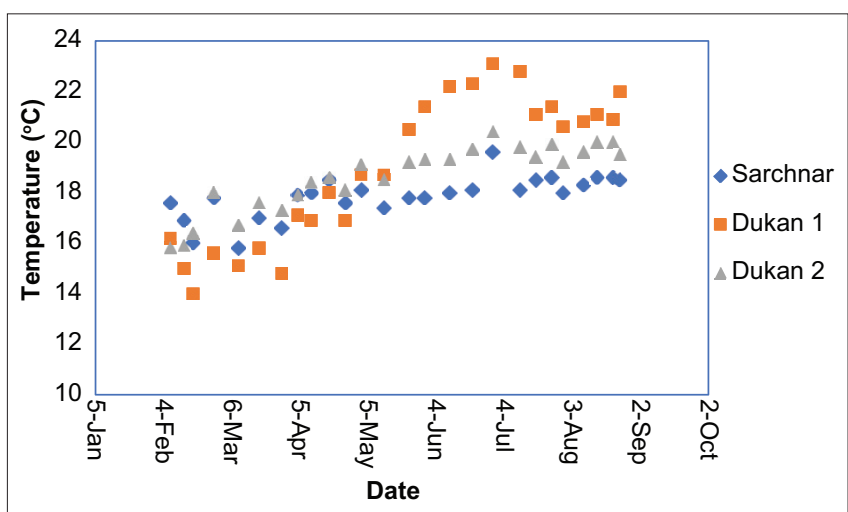

Fig. 2. Temporal variation of temperature.

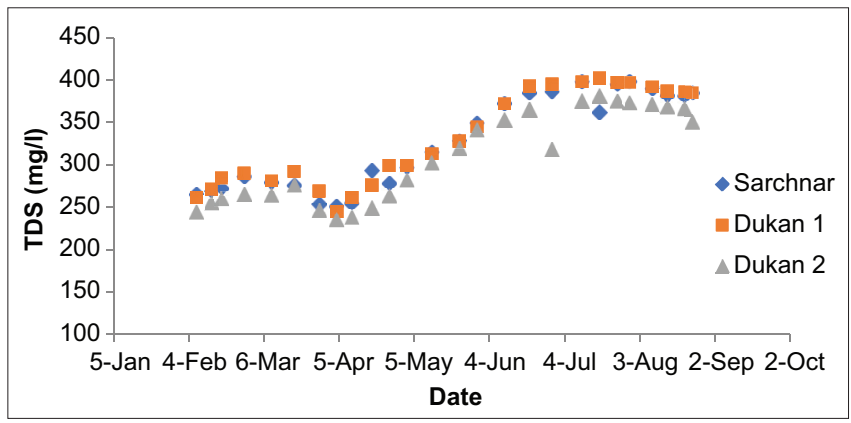

Fig. 3. Temporal variation of total dissolved solids.

shows that the results of PH for the three sources were close, and the results were raised during the flood events occurred in February and March. The average value of PH for Sarchnar, Dukan 1, and Dukan 2 was 7.7, 7.66, and 7.72, respectively. As the alkalinity has a high correlation to $\mathrm{pH}$ through buffering water against excessive change of $\mathrm{PH}$, the same trend of $\mathrm{pH}$ is observed in its plot against time.

Maximum permissible limit of total alkalinity according to the WHO standards is $600 \mathrm{mg} / \mathrm{l}$. In the current study, total alkalinity with the range of $130-235 \mathrm{mg} / 1$ was recorded for all water samples. The value of total alkalinity was lower in rainy seasons than in the arid one. Furthermore, the results of Sarchnar water samples were close to Dukan 1, but Dukan 2 water samples recorded lower results.

Turbidity as one of important parameter for drinking water should be under 5 NTU, the average results of turbidity were within the standards which were 1.9 NTU for Sarchnar and Dukan 1 and 2.43 NTU for Dukan 2. However, the value of turbidity was raised significantly to the highest value which was 10.5, 11.6, and 14.1 NTU for Sarchnar, Dukan Lane 1, and Dukan lane 2, respectively, because of the storm occurred

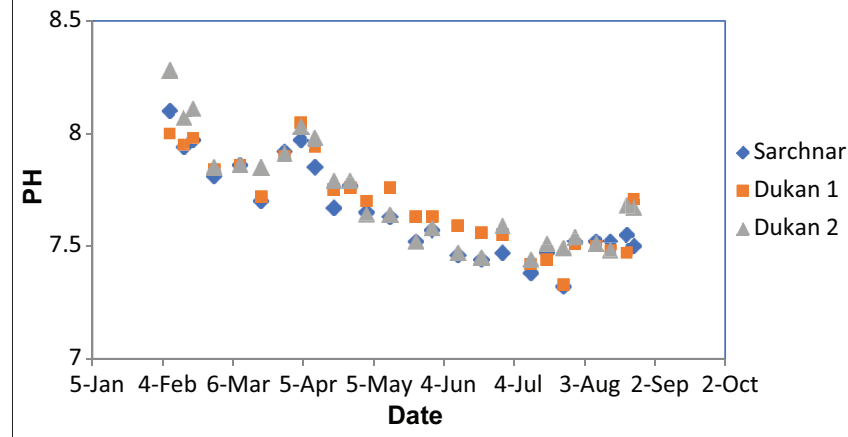

Fig. 4. Temporal variation of $\mathrm{PH}$.

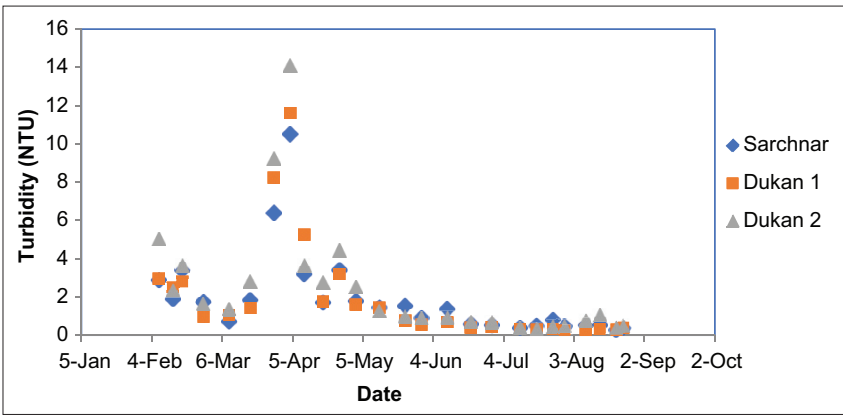

Fig. 5. Temporal variation of turbidity.

in the beginning of April. In summer season, the value of turbidity reached the minimum value of $0.26 \mathrm{NTU}$ and it remains around this value until the end of the study without significant change (Fig. 5).

Fig. 6 shows that the amounts of free chlorine residual in the collected samples from Dukan 1 have the lower values ranged between 0 and $0.5 \mathrm{mg} / 1$, samples from Sarchnar ranged between 0 and $1 \mathrm{mg} / 1$ and Dukan 2 have the higher values $(0.5-2 \mathrm{mg} / \mathrm{l})$. Because the Dukan 2 source feeds water to the far neighborhoods in the city, the amount of free chlorine was higher than the other sources so as to insure obtaining safe water to the residential. The results of free chlorine residual concentration in the water samples were ranged between 0.11 and $1.96 \mathrm{mg} / \mathrm{l}$ which were within the recommended value in the WHO standards [19] and Iraqi water specifications [26].

The mean concentration of ammonia and ammonium in this study was very low (0.02 and $0.03 \mathrm{mg} / \mathrm{l})$ for all water sources which were below the standard limit $(1.5 \mathrm{mg} / \mathrm{l})$. The results of ammonia and ammonium for the three sources were close to each other during the period of the study except in several data for Sarchnar which were higher than the other with the value around $(0.08 \mathrm{mg} / \mathrm{l})$. Fig. 7 shows temporal variation of ammonia in the three sources of water. 
According to the drinking water quality standards, the limit of hardness should be within the limit of $500 \mathrm{mg} / \mathrm{l}$. The value of hardness for all water samples was between 120 and $200 \mathrm{mg} / 1 \mathrm{CaCO}_{3}$ which was below the permissible value. Fig. 8 represents that the range of hardness for the water samples from Sarchnar and Dukan1 was close and the average range was around $150 \mathrm{mg} / 1 \mathrm{CaCO}_{3}$. The average value of hardness in Dukan 2 was $145 \mathrm{mg} / \mathrm{l} \mathrm{CaCO}_{3}$.

In this study, the average value of calcium concentration for the three sources was around $60 \mathrm{mg} / 1$ which was within the recommended limit $(75 \mathrm{mg} / \mathrm{l})$. As shown in Fig. 9, most of the calcium concentration results for the three sources were close and all values during the study were below the standard limit except in two data recorded for Dukan 1 water samples which exceeded the standard limit with the value of $78 \mathrm{mg} / \mathrm{l}$.

According to the WHO guidelines for drinking water standards [19], fluoride concentration should be under $1.5 \mathrm{mg} / \mathrm{l}$. In the current study, fluoride mean value was $0.21 \mathrm{mg} / \mathrm{l}$ for all sources of drinking water. At the beginning of the study, minimum results were recorded which were sometimes near zero. The value of fluoride concentration continued rising until August, this rising was continued in Sarchnar water samples but Dukan 1 and 2 water samples

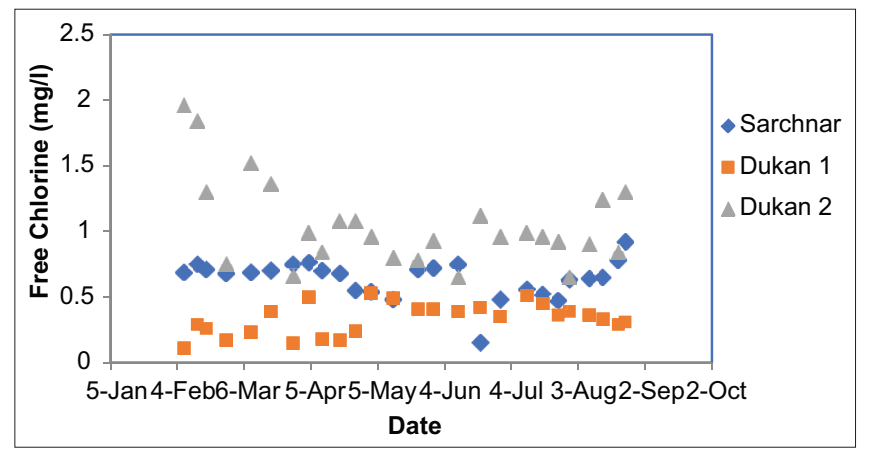

Fig. 6. Temporal variation of free chlorine.

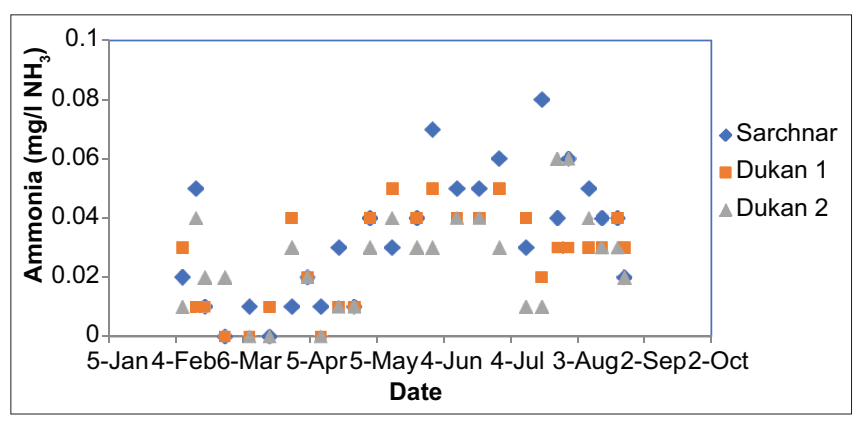

Fig. 7. Temporal variation of ammonium. started falling until the end of the study (Fig. 10). The fluoride level all the time is below the recommended level of $0.7 \mathrm{mg} / 1$ for healthy teeth enamel.

Minimum observed that results of chloride for the three water sources during the study were recorded in winter season which were between 0 and $1 \mathrm{mg} / 1$. Most of the chloride values were ranged between 1 and $10 \mathrm{mg} / \mathrm{l}$, but in May 12 the concentration of chloride for water samples from Sarchnar and Dukan 1 reached maximum value which was $18 \mathrm{mg} / 1$ and $15 \mathrm{mg} / \mathrm{l}$, respectively (Fig. 11). The average value of chloride concentration in the study was $5 \mathrm{mg} / \mathrm{l}$ which was below the permissible value of $250 \mathrm{mg} / \mathrm{l}$. In this study, the mean values of nitrate nitrogen and nitrate were $3.5 \mathrm{mg} / 1 \mathrm{~N}$ and $15.6 \mathrm{mg} / 1 \mathrm{NO}_{3}$, respectively, which were below the

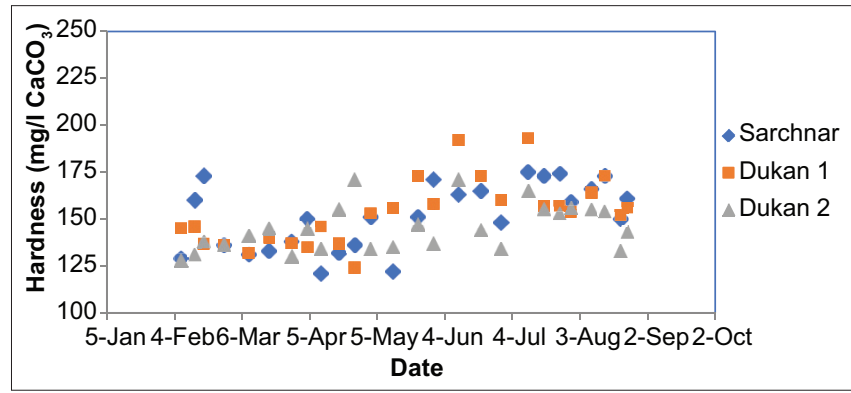

Fig. 8. Temporal variation of hardness.

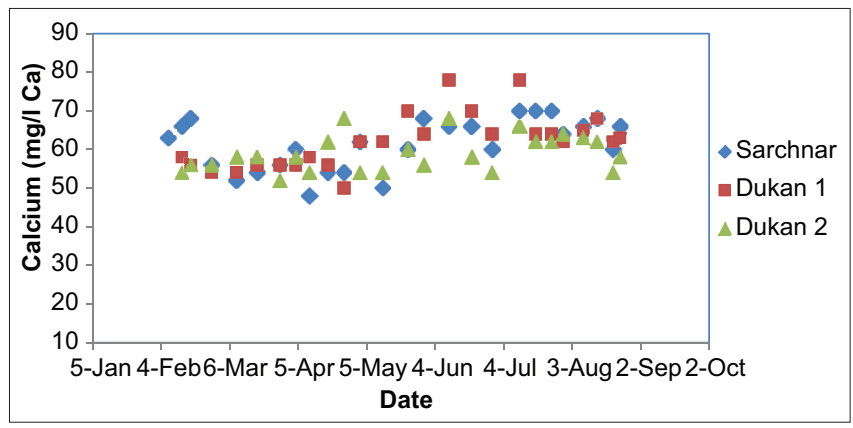

Fig. 9. Temporal variation of calcium.

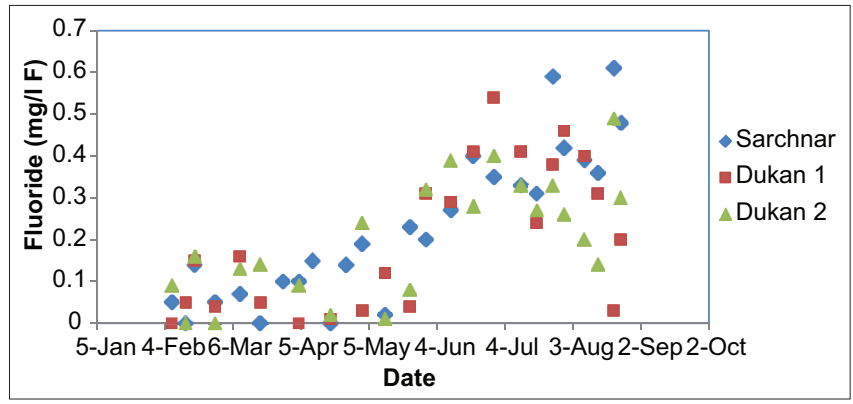

Fig. 10. Temporal variation of fluoride.

UHD Journal of Science and Technology | Jul 2020 | Vol 4 | Issue 2 


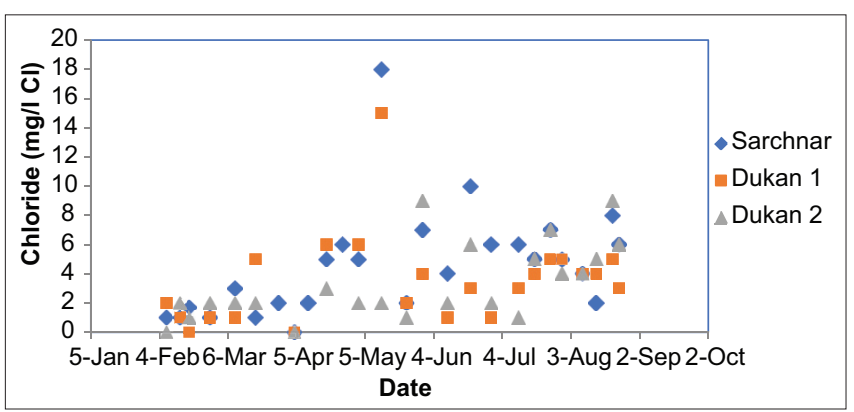

Fig. 11. Temporal variation of chloride.

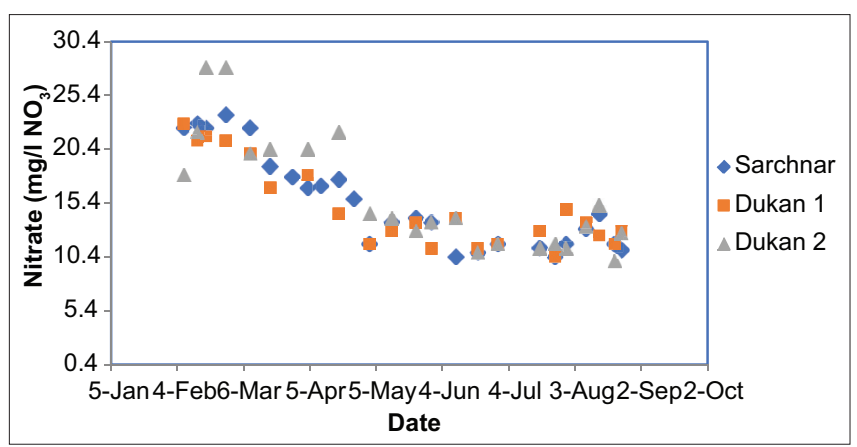

Fig. 12. Temporal variation of nitrate $\left(\mathrm{NO}_{3}\right)$.

permissible limits according to standards $(10 \mathrm{mg} / \mathrm{l}$ of nitrate nitrogen and $50 \mathrm{mg} / \mathrm{l}$ of nitrate).

Fig. 12 shows that the results of nitrate concentration in the three water sources are similar starting from highest value in the winter season and then decreasing to the lower values in summer season. The reason of increasing the amount of nitrate during the rainy season may be due the agricultural runoff which is one of the main sources of occurring nitrate in water [19], and [21].

\section{CONCLUSIONS}

From the results of this study, it can be concluded that, in general, the quality of water at the sources of Sulaimani City is suitable for drinking purpose, because the analyzed physical and chemical parameters of water samples during the period of the study were mostly within the standards recommended by the WHO guidelines [19] and Iraqi specifications [26]. However, there was some turbidity exceedance of the permissible level during flood events and high rainfall events. Furthermore, the level of fluoride exists in the water is below the standard level for healthy teeth which is between $0.7 \mathrm{mg} / \mathrm{l}$ and $1.5 \mathrm{mg} / \mathrm{l}$. Even though, the Sarchnar source is natural spring and different from the other sources, but high differences were not observed in the results of measurements between the sources. This may be because of huge amount of water in lake this year due to the significant high amount of rainfall during the period of study which can dilute contaminants in the impounded water. Finally, this study recommends addition a pretreatment unit to be used during flood events to reduce the turbidity and addition of fluoride to the drinking water to restore and strengthening the users' teeth enamel. Furthermore, it is crucial and important for future researches and water quality monitoring to include heavy metal and disinfection water quality parameters.

\section{REFERENCES}

[1] C. Prakirake, P. Chaiprasert and S. Tripetchkul. "Development of specific water quality index for water supply in Thailand". Songklanakarin Journal of Science and Technology, vol. 31, no. 1, pp. 91-104, 2009.

[2] A. H. M. Alobaidy, H. S. Abid and B. K. Maulood. "Application of water quality index for assessment of Dokan lake ecosystem, Kurdistan region, Iraq". Journal of Water Resource and Protection, vol. 2, no. 9, p. 792, 2010.

[3] A. C. AL-Shammary, M. F. AL-Ali and K. H. Yonuis. "Assessment of Al-Hammar marsh water by uses Canadian water quality index (WQI)". Mesopotamia Environmental Journal, vol. 1, no. 2, pp. 2634, 2015.

[4] E. D. Ongley. Water quality management: Design, financing and sustainability considerations-II. In: Invited Presentation at the World Bank's Water Week Conference: Towards a Strategy for Managing Water Quality Management. World Bank, United States, 2000.

[5] A. Sargaonkar and V. Deshpande. "Development of an overall index of pollution for surface water based on a general classification scheme in Indian context". Environmental Monitoring and Assessment, vol. 89, no. 1, pp. 43-67, 2003.

[6] K. Mosimanegape. Integration of Physicochemical Assessment of Water Quality with Remote Sensing Techniques for the Dikgathong Damin Botswana. Master's Dissertation, University of Zimbabwe, Harare, 2016.

[7] H. J. Vaux. "Water quality (book review)". Environment, vol. 43, no. 3, p. 39, 2001.

[8] A. Parparov, K. D. Hambright, L. Hakanson and A. Ostapenia. "Water quality quantification: Basics and implementation". Hydrobiologia, vol. 560, no. 1, pp. 227-237, 2006.

[9] A. H. M. Alobaidy, B. K. Maulood and A. J. Kadhem. "Evaluating raw and treated water quality of Tigris River within Baghdad by index analysis". Journal of Water Resource and Protection, vol. 2, no. 7 , pp. 629, 2010.

[10] H. C. Kataria, M. Gupta, M. Kumar, S. Kushwaha, S. Kashyap, S. Trivedi and N. K. Bandewar. "Study of physico-chemical parameters of drinking water of Bhopal city with reference to health impacts". Current World Environment, vol. 6, no. 1, pp. 95-99, 2011.]

[11] H. Q. Khan. Water quality index for municipal water supply of Attock city, Punjab, Pakistan. In: Survival and Sustainability. Springer, Berlin, Heidelberg, 2010.

[12] M. Alsawalha. "Assessing drinking water quality in Jubail industrial city, Saudi Arabia”. American Journal of Water Resources, vol. 5, 
no. 5, pp. $142-145,2017$.

[13] N. Othman, T. Kane, and K. Hawrami. Environmental health assessment in Sulaymaniyah city and Vicinity. Tech Report, United States, 2017.

[14] H. M. Issa and R. A. Alrwai. "Long-term drinking water quality assessment using index and multivariate statistical analysis for three water treatment plants of Erbil City, Iraq". UKH Journal of Science and Engineering, vol. 2, no. 2, pp. 39-48, 2018.

[15] F. Salih, N. Othman, F. Muhidin and A. Kasem. "Assessment of the quality of water in Sulaimaniyah city, Kurdistan region: Iraq". Current World Environment, vol. 10, no. 3, pp. 781-791, 2015.

[16] D. A. M. Barznji and D.G.A. Ganjo. "Assessment of the chemical water quality in Halabja-Sulaimani, Kurdistan region of Iraq". Asian Journal of Water Environmental and Pollution, vol. 11, no. 2, pp. 19-28, 2014.

[17] Y. A. Hamaamin. "Developing of rainfall intensity-durationfrequency model for Sulaimani city". Journal of Zankoy Sulaimani, vol. 19, no. 3-4, p10634, 2017.

[18] S. M. Razuki and M. A. Al-Rawi. Study of some physiochemical and microbial properties of local and imported bottled water in Baghdad city. Iraq Journal of Market Research and Consumer Protection, vol. 2, no. 3, pp. 1-7, 2010.
[19] World Health Organization. Guidelines for Drinking-water Quality: First Addendum. $4^{\text {th }}$ ed. World Health Organization, Geneva, 2017.

[20] C. E. Boyd. Water Quality: An Introduction. $3^{\text {rd }}$ ed. Springer, Berlin, Germany, 2015

[21] Environmental Protection Agency. Parameters of Water Quality: Interpretation and Standards. Environmental Protection Agency, United States, 2001.

[22] M. V. Ahipathy and E. T. Puttaiah. "Ecological characteristics of Vrishabawathi River in Bangalore (India)". Environmental Geology, vol. 49, no. 8, pp. 1217-1222, 2006.

[23] $\mathrm{H}$. Boyacioglu and $\mathrm{H}$. Boyacioglu. "Surface water quality assessment by environmetric methods". Environmental Monitoring and Assessment, vol. 131, no. 1-3, pp. 371-376, 2007.

[24] World Health Organization. Guidelines for Drinking-water Quality: Incorporating First and Second Addenda. $3^{\text {rd }}$ ed., Vol. 1, World Health Organization, Geneva, 2008.

[25] L. Apha, A. Clesceri and A. Greenberg. Standard Methods for the Examination of Water and Wastewater. $20^{\text {th }}$ ed. American Public Health Association, Washington, DC, 1998.

[26] ICSD, WCL. Iraqi Criteria and Standards for Drinking Water, Chemical Limits. ICS: 13.060 .20 , IQS: 417, $2^{\text {nd }}$ Update 2009 for Chemical and Physical Limits. ICSD, WCL, United States, 2009. 